\title{
Comprehensive agricultural support programme as the prime mover of agricultural development agenda in South Africa
}

Mncina S.D. ${ }^{1}$ and Agholor A.I. ${ }^{2}$

Corresponding author: Agholor A.I. Email: isaac.agholor@ump.ac.za

\begin{abstract}
The agricultural support initiatives in South Africa are numerous and are aimed at reducing poverty. One of these progressive support initiatives for agricultural development in South Africa is the Comprehensive Agricultural Support Programme (CASP). The paper examined the various levels of investments in CASP, evaluated the prospects and challenges, and bench marked the national and provincial investment and implications for extension in South Africa. For the purpose of this study, qualitative methods involving the review of government commissioned reports, working papers, key debates on CASP, online sources, books, peer reviewed journals, etc. were used. The study found that prioritisation of resource allocation is essential in supporting long-term government investments for CASP. The gap in knowledge and information regarding the nature and status of CASP in agricultural development cannot be overemphasised. Reflecting on the findings, a coordinated policy environment to allow the support and participation of the private business investors to fill the investment gap in agriculture is recommended. Furthermore, investing in the prime movers of agriculture: agricultural research and development, human capital development, biophysical capital formation, and improved institutions remains distinctive.
\end{abstract}

Key words: Agriculture, development agenda, prioritisation, investment, prime movers

\section{INTRODUCTION}

The effective use of public funds has been instrumental in laying the foundations for agricultural growth around the world and providing important lessons for African policymakers and development partners. Investment in rural agriculture, combined with better policies and institutions, is the driver of agricultural productivity and growth (Goyal and Nash, 2016:27). The agricultural support initiatives in South Africa are numerous and are aimed at reducing poverty. One of these progressive provisions for agriculture development in South Africa is the Comprehensive Agricultural Support Programme (CASP). The CASP primary purpose is to provide effective agricultural support towards agricultural development and to streamline the

\footnotetext{
${ }^{1}$ Lecturer: School of Agriculture, Agricultural Extension \& Rural Resource Management. Faculty of Agriculture and Natural Sciences, University of Mpumalanga. Private Bag X11283, Nelspruit, 1200. Tel: 01300264 Email: Sithembile.mncina@ump.ac.za

${ }^{2}$ Senior Lecturer: School of Agriculture, Agricultural Extension \& Rural Resource Management. Faculty of Agriculture and Natural Sciences, University of Mpumalanga. Private Bag X11283, Nelspruit, 1200. Tel +27-(0)130020131. Email: Isaac.agholor@ump.ac.za, ORCID NO: $\underline{0000-0001-8559-0246}$
} 
provision of services to address the problem of lack of access to farmer support services in order to improve and facilitate agricultural development, particularly, for smallholder agriculture (Department of Agriculture, Forestry and Fisheries, 2014:3). The prime movers of agricultural development in South Africa include: agricultural research and development, human capital, biophysical capital formation, improved institutions, particularly, rural institutions, and an ideal macroeconomic and agricultural policy environment.

Government investment in agricultural development is one of the key instrument available for promoting economic growth (Binuomote et al., 2012: 9). Investing in the prime movers of agriculture has been identified as one of the most effective ways to promoting agricultural development. While productivity of African agriculture has grown, it still lags behind Asia and Latin America, and has not delivered the development dividends needed to significantly reduce poverty in rural areas across sub-Saharan Africa (Goyal \& Nash, 2016:14). One key element that can accelerate change and unleash growth is to allow a shift towards more effective, efficient and higher government spending in agriculture. This is necessary for enhancing agricultural productivity by refining productive investment in agriculture. In 2003, African nations launched the Comprehensive Africa Agriculture Development Programme (CAADP), popularly known as the Maputo Declaration whose aim amongst others was to invest ten per cent of national government spending on agriculture. This target was reiterated in the 2014 Malabo Declaration, and CAADP led the charge to support national teams working in the agricultural sector to conduct basic agriculture government expenditure reviews and analysis (Goyal \& Nash, 2016:60).

In South Africa the government has also adopted a number of approaches towards investing in the prime movers of agriculture. In South Africa, the Comprehensive Agricultural Support Programme since its inception in 2004/05 and running through 2011/12, received a total of R4, 306 billion for investment in the prime movers of agriculture by the National and Provincial Departments of Agriculture (DAFF, 2012:12). However, a number of issues around government investment in prime movers remain vague. Firstly, little is known about the extent of prioritisation to which the CASP programme has invested in the five prime movers of agriculture (Liebenberg, 2015:19; National Planning Commission (NPC), 2011:32). Secondly, there is concern that the amount invested in each prime mover among the provinces within Comprehensive Agricultural Support Programme are not known. Also, there is paucity of information regarding the nature and status of government investments in the prime movers of the South African agriculture, particularly, at lower levels. Finally, whilst government investments in the prime movers of agriculture is expected to have a significant effect on the economy, the relationship between the investments through CASP and agricultural development of the provinces also remain questionable. This study attempt to provide insight for policy makers to understand the significance of prioritising government investments on the five prime movers of agricultural development, determine the levels of government investments in CASP as the prime mover of agricultural development agenda and evaluate the prospects and challenges of CASP in South Africa. 


\subsection{Objectives of the study}

i. To highlight the levels of government investments in CASP as the prime mover of agricultural development agenda in South Africa.

ii. Examine the prospects and challenges of CASP implementation in South Africa.

iii. Document the national and provincial benchmarks of South African investment in CASP

iv. State the agricultural extension implications of CASP in South Africa.

\section{METHODOLOGY}

The study examined the various levels of investments in CASP, evaluated the prospects and challenges, and bench marked the national and provincial investment and implication for extension in South Africa. For the purpose of this study, a qualitative method involving the review of government commissioned reports, working papers, key debates on CASP, online sources, books, peer reviewed journals, was used.

\section{RESULTS AND DISCUSSION}

The paper outlines the stages of government investments in CASP as the prime mover of the agricultural development agenda in South Africa; evaluated the prospects and challenges of CASP; examined the national and provincial benchmark investments in CASP. Extension implication for CASP was also extensively highlighted.

\subsection{Government investment in CASP as the prime mover of agricultural development agenda in South Africa.}

Government investment in the prime movers of agricultural development has been identified as one of the fundamental tool available for stimulating economic growth in Sub-Saharan Africa.

\subsubsection{Agricultural research and development}

Over the last decade, spending on agricultural research and development amounted to about 0.4 per cent in Sub-Saharan Africa as compared to 1.3 per cent in Latin America and the Caribbean, 0.6 per cent in East Asia and the Pacific, and 0.9 percent in South Asia (Goyal \& Nash, 2016:59; Norton, et al., 2010:15; Binuomote et al., 2012:19). So far, the less developed countries are under investing in agricultural research with South Africa as a case in point. This is evident from the fact that the intended public investment in research of one per cent of Gross Domestic Product (GDP) for overall science research has not been achieved (Flaherty et al, 2010:8). Nonetheless, Norton, Alwang and Master (2010:19) argued that a major determinant of growth in agricultural production is the effectiveness of agricultural research. In addition, 
Binuomote, Adeleke and Omodunbi (2012:43) also alluded to the fact that public spending on research, extension and education normally leads to improvements in the stock of modern technologies and knowledge of human resources which is expected to raise the productivity of all factors of production. It is through research that the productivity of existing resources are increased, new higher-productivity inputs and ways of producing food developed (Norton et al., 2010:7). (Goyal \& Nash, 2016:68). The six cardinal pillars of Comprehensive African Agricultural Development Programmes' (CAADP) focuses on increasing investments in agricultural research, extension, education, and training as a means of promoting growth in agricultural productivity which indicates that some of the prime movers of agricultural development are covered by the programme (New Partnership for Africa's Development (NEPAD)-CAADP, 2010:12).

\subsubsection{Agriculture and human capital development}

Agricultural development is one of the most powerful avenue to end extreme poverty, and boosting shared prosperity. Growth in the agricultural sector is two to four times more effective in raising incomes among the poorest compared to other sectors. For example, a study conducted by the Food and Agriculture Organization (2016:10) found that sixty five per cent of poor working adults made a living through agriculture which also accounted for one third of global GDP. Several theories (Bleakley, 2010:2; Woode, 2017:38) have connected human capital development to issues such as: health, education, economic development, productivity growth, and innovation. Conversely, researchers have also stressed the need for education and quality investment in human capital for productivity enhancement in agriculture (Mohammad \& Jalil, 2011:44). Therefore, the development of human capital is key to innovation and the acceleration of agricultural growth (Singh \& Pal, 2010:8).

Given the complexity of the agriculture workforce, skills, and training issues, a strategic approach between government and industry is crucial. It is of importance that human capital conceptualise the benefits of public spending in agriculture along four pathways: generating technology, disseminating knowledge, reducing transaction costs, and attracting private capital (Goyal \& Nash, 2016:69). This is so because development and provision of public goods by human being are complementary in nature, thus, it is difficult to assess a comprehensive agricultural investment without including: improvements in land, development of natural resources, human and social capital, in addition, to physical capital formation which is critical for agricultural development (Food and Agriculture Organization (FAO), 2012:2).

\subsubsection{Biophysical capital formation for agricultural development}

The government spending on biological capital which includes agricultural inputs (fertilizer and improved seeds) may increase because these inputs are subsidised (Binuomote, Adeleke and Omodunbi, 2012:32), These enabling environment is likely to encourage farmers to invest in their agricultural land, especially in activities that protect the land from soil erosion by 
practicing for example, terracing and mulching, adding rock or soil bunds to enhance productivity.

\subsubsection{Institutional improvement and rural institutions}

The provision of public goods is essential in building the institutions and human capital necessary to support an enabling environment for agricultural investment. In the rural areas, for example, investments in public goods are most likely to be complementary in nature such that investments in education and rural infrastructure tend to enhance agricultural investment and are often ranked among the top sources of agricultural growth and overall economic growth (Food and Agricultural Organization, 2012:3). The Green Revolution, for example, shows that a strategy of strong public support for agriculture paid rich dividends in the Indian agricultural sector. Though, most of the initial agricultural public investment in South Africa was directed at irrigation infrastructure and eventually extended to include other areas, such as agricultural research and development, rural electrification, animal health, public provision of critical inputs and agricultural product markets resulting in an increase in agricultural development (Singh and Pal, 2010:2; Goyal and Nash, 2016:12)

\subsubsection{Creating an enabling agricultural policy environment}

Successful cases of agricultural transformation have shown that creating an enabling environment for farmers and the private sector to invest in agriculture is a fundamental prerequisite (CAPSA, 2012:2). The Food and Agriculture Organization (2012:4) summarise the elements of a favourable general investment climate as being many of the same factors which are more important in creating an enabling environment for agricultural investment. These include: (a) good governance; (b) macroeconomic stability; (c) transparent and stable trade policies; (d) effective market institutions; and (e) respect for property rights. According to Gore and Shinde (2014), behaviour of public investment in agriculture is largely explained by agriculture policies of the time. Goyal \& Nash, 2016:267 asserted that in most Sub-Saharan Africa, categories of spending that have substantial positive outcome on productivity and welfare are not directed towards agriculture while others with less significant effects, habitually capture large percentages of government budget. Therefore, improving the efficiency of public spending requires managing the political pressures that determine budget allocations. However, failure to provide adequate infrastructure, institutions and public services in the rural areas and the waste of scarce public resources all increase the costs and risks associated with agriculture and drastically reduce incentives for private investment in the sector (FAO, 2012:6). Hence, the next section provides an overview of the successes and failures of CASP concerning public investments in the five prime movers of agricultural development in South Africa. 


\section{PROSPECTS AND CHALLENGES OF CASP IMPLEMENTATION IN SOUTH AFRICA}

The performance of the South African agricultural sector and the development of rural areas is inextricably linked to the government priorities and budgetary allocation. Hence, the ability of the agricultural sector to sustain broad-based, pro-poor development and income growth depends primarily on stated priorities and actions of the South African government (Hall and Aliber, 2010:5). Soon after democracy in 1994, the Department of Agriculture (DoA) attached great importance to delivering affective agricultural support services to the agricultural community, particularly, previously disadvantaged subsistence, emerging and commercial farmers. Its vision was to have a united and prosperous agricultural sector in South Africa (Business Enterprises (BE), 2015). Consequently, commercial farmers had access to land, finance, mechanisation, labour and national as well as export markets (Kibuuka and Mnyaka, 2013:15). The recognition has also led to the comprehension that agriculture is critical for livelihood to the rural poor to whom other sources of income are unsustainable. However, this role of agriculture has always remained weakened because of both colonisation and apartheid. In addition, it is also becoming increasingly unimportant as a result of the increases in both social grants and employment opportunities elsewhere (NPC, 2011:3). Nonetheless, it has been recognised that agricultural development is important in South Africa because it is a precursor for both rural welfare and for overall economic development (Norton et al., 2010:14).

In this era of technological advancement, a comprehensive and reliable public investment database in the prime movers of agricultural development is vital for the planning and execution of agricultural programmes (Mogues et al., 2012:28). Indeed, in South Africa since 1994 the Department of Agriculture now known as the Department of Agriculture, Forestry and Fisheries has developed and implemented policies to address the imbalance regarding smallholder farmers support programmes. It has also emphasised the need to support smallholder farmers because this would offer long term solutions to the problems of unemployment and rural neglect (Sikwela \& Mushunje, 2013:14). It is recognised that the policy choices and agricultural budgetary allocations have implications for approximately 8.5 million people who depend either directly or indirectly on agriculture for employment and an income (van Niekert, 2012:9). Access to agricultural support services is essential for increasing agricultural growth, particularly, in smallholder agriculture. In South Africa, however, inadequate access to agricultural support services and post-settlement support has been identified as a major reason for the poor performance of many land reform projects (BE, 2015:22; Binswanger-Mkhize, 2014:10). Numerous studies in South Africa has assessed the benefits of agricultural productivity growth for both economic growth and poverty reduction (Bhorat et al., 2011:9; Grewal et al, 2012:16). However, it is suggested that the potential of agriculture to expand has not happened as a result of the lack of a favourable agricultural policy environment (NPC, 2011:2). 


\subsection{Challenges of CASP implementation in South Africa}

Majority of the provinces benefiting through the Comprehensive Agricultural Support Programme have not improved significantly in enhanced productivity (Jacobs et al., 2010:5). Although the Comprehensive Agricultural Support Programme, as the name suggests, is supposed to be a comprehensive programme, its implementation efforts in the past have focused mainly on infrastructural provision. This is one of the major challenges, recognised that since the inception of the programme in 2004, that it has been biased in favour of infrastructure development. This means that the bulk of programme funding is allocated to infrastructural projects. It has also been observed that the national and provincial departments of agriculture provide training without any prior skills-needs assessment even though training of farmers were usually offered by agricultural colleges and accredited service providers (PSC, 201:2).

Among the challenges experienced in the implementation of the Comprehensive Agriculture Support Programme were: (a) aligning budgets and systems between the then Department of Land Affairs, Department of Agriculture, and Provincial Department of Agriculture; (b) implementing priorities with regard to infrastructure in the communal areas; (c) stepping up capacity building and technical advice for land reform beneficiaries; and (d) integrating the Agriculture Starter Pack into the household food production programme (Ministry of Agriculture and Land Affairs, 2006:12:7).

The paucity and late arrival of post-settlement support has also been a major problem in land reform programmes in Sub-Saharan Africa. In South Africa, the acquisition of land was assigned to the Department of Rural Development and Land Reform while post-settlement remains at the provincial Department of Agriculture. This separation gave way to unnecessary bureaucracy and multiplicity of functions. Therefore, it is not surprising that there is poor settlement support which has significantly undermined the goal of creating successful farms in South Africa. For instance, investments and inputs are often delayed by months or years. Moreover, the investments are often not based on the needs of beneficiaries and inputs often arrive late, marketing support is largely left out and increases in production, food security, employment and market access are insignificant (BE, 2014:10).

Despite a sharp increase in the comprehensive agricultural support programme budget over the years, the number of individual beneficiaries has dropped. Emphasis on the development of individual farm infrastructure severely limits the impact of public agricultural expenditure (Programme to Support Pro-poor Policy Development, 2011:3). Therefore, for the agricultural sector to contribute to the South African economic growth, the budget process should depend on a number of factors, such as, the availability of funds, access and proper use of technology, human capital, and functional agricultural markets (Gauteng Provincial Government Economic Review and Outlook, 2012:9). 
While the contribution of agriculture to household income is small, evidence from studies (Ministry of Agriculture and Land Affairs, 2006:12:61; BE, 201:19) abound that small-scale and commercial agriculture in the former homelands is undergoing a decline. The common cited reason for this decline is the removal of the minimal support that farmers in former homelands used to receive from pre-1994 governments (Grewal et al., 2012:34). Literature also indicates that there is disparity in the national performance of many Comprehensive Agricultural Support Programmes at project level between the planned, dropped and continued as well as completed projects. Furthermore, supported beneficiaries differ tremendously from the targeted beneficiaries, and more males are engaged nationally compared to females. CASP should also target more women, youth and disable persons. It can be argued, therefore, that delivery challenges that were highlighted in the 2004/05 Comprehensive Agricultural Support Programme annual report were also repeated in the 2008/09 annual report, which means that these delivery challenges have not been resolved since the inception of the programme (DAFF, 2012:4; PSC, 2011:13; BE, 201:7).

\section{THE NATIONAL AND PROVINCIAL BENCHMARK AND INVESTMENTS IN CASP}

The national and provincial benchmark for CASP encapsulate the delivery mechanism which is underpinned by three pillars, namely, cooperation between partners and the alignment of strategies, clear definition of role and responsibilities of the partners and clear analysis of the resources available to fund the programme (PSC, 2011:5). The state-sponsored agricultural schemes generally focus on addressing the resource gap, such as, improving access to land and credit and developing infrastructure. The private sector initiatives, on the other hand, focus on coordination issues, skills development and mentorship which facilitate access to higher value chains or better markets for smallholder farmers (Sikwela and Mushunje, 2013:12).

There are six priority areas or pillars that have been identified to facilitate agricultural support for the four categories of targeted beneficiaries of the Comprehensive Agricultural Support Programme as illustrated in Figure 1 (DoA, 2004:5; PSC, 2011:13). 


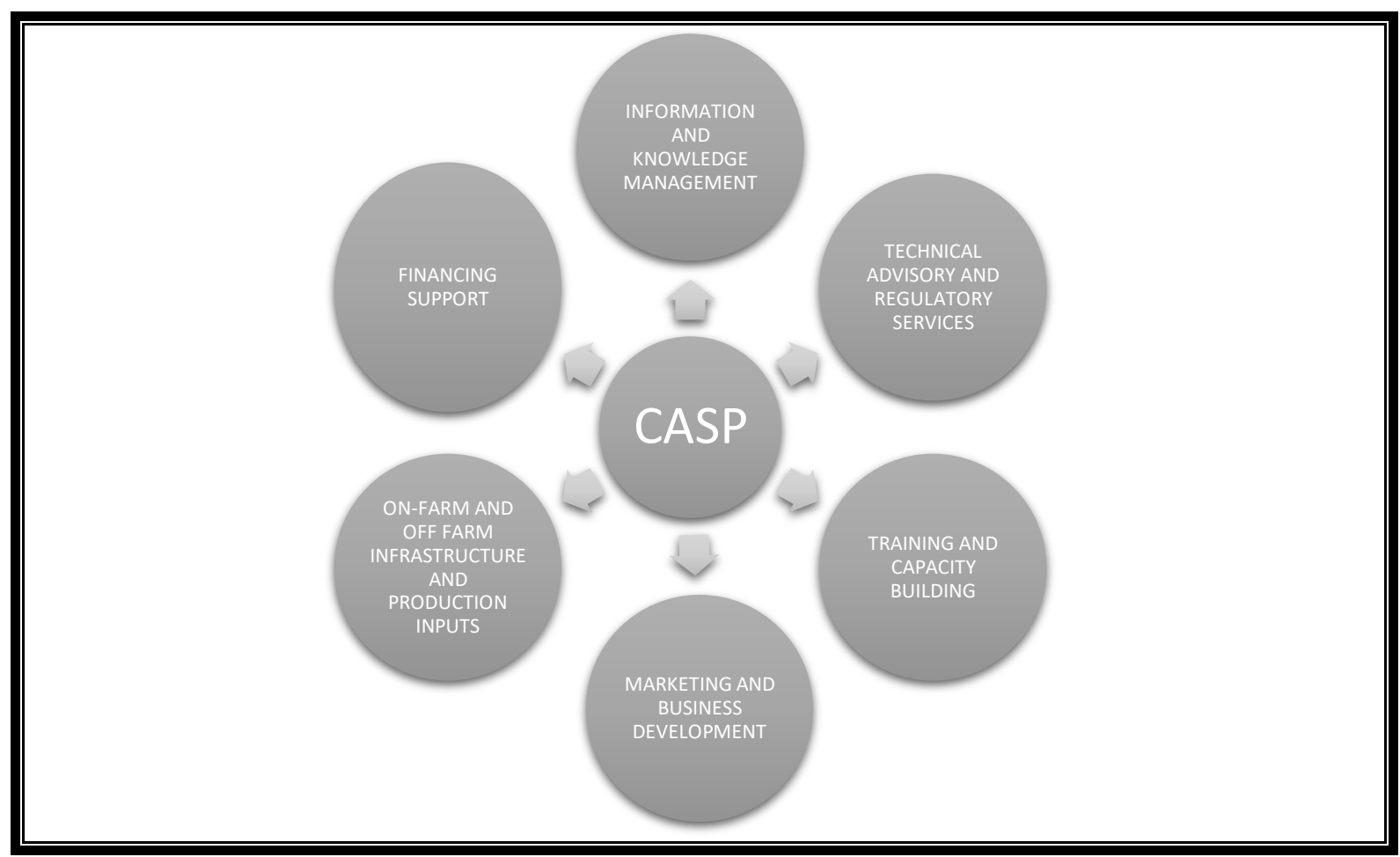

Figure 1 The six pillars or priority areas of Comprehensive Agriculture Support

\section{Programme}

Source: Public Service Commission 2011. An Evaluation of the Comprehensive Agriculture Support Programme (CASP).

These six priority areas are: (a) information and knowledge management; (b) technical and advisory assistance, and regulatory services; (c) training and capacity building; (d) marketing and business development; (e) on-farm and off-farm infrastructure and production inputs; and (f) financial assistance. Apart from having a database of the targeted beneficiaries of the Comprehensive Agriculture Support Programme and their programmes or projects for planning, budgeting and reporting, beneficiary addresses or database are also needed for communication purposes. It is also envisaged that provinces and local governments need to have this information in order to link with that of the national Department of Agriculture (DoA, 2004). It can also be argued that all the five categories of prime movers of agricultural development are covered by the Comprehensive Agriculture Support Programme although using different criteria among the provinces, and the service delivery mechanism is defined as well as the major stakeholders or role players of agricultural support for farmers. One pillar, which is the financial support is provided by Micro Agricultural Financial Institutions of South Africa (MAFISA) (DoA, 2004:2; PSC, 2011:17).

CASP is targeted to support four different levels of clients within the farming continuum, including: (a) the hungry and malnourished; (b) subsistence and household food producers; (c) the farmers; and (d) the general public operating within the macro-economic environment as shown in Figure 2 (DoA, 2004:5; PSC, 2011:13). 


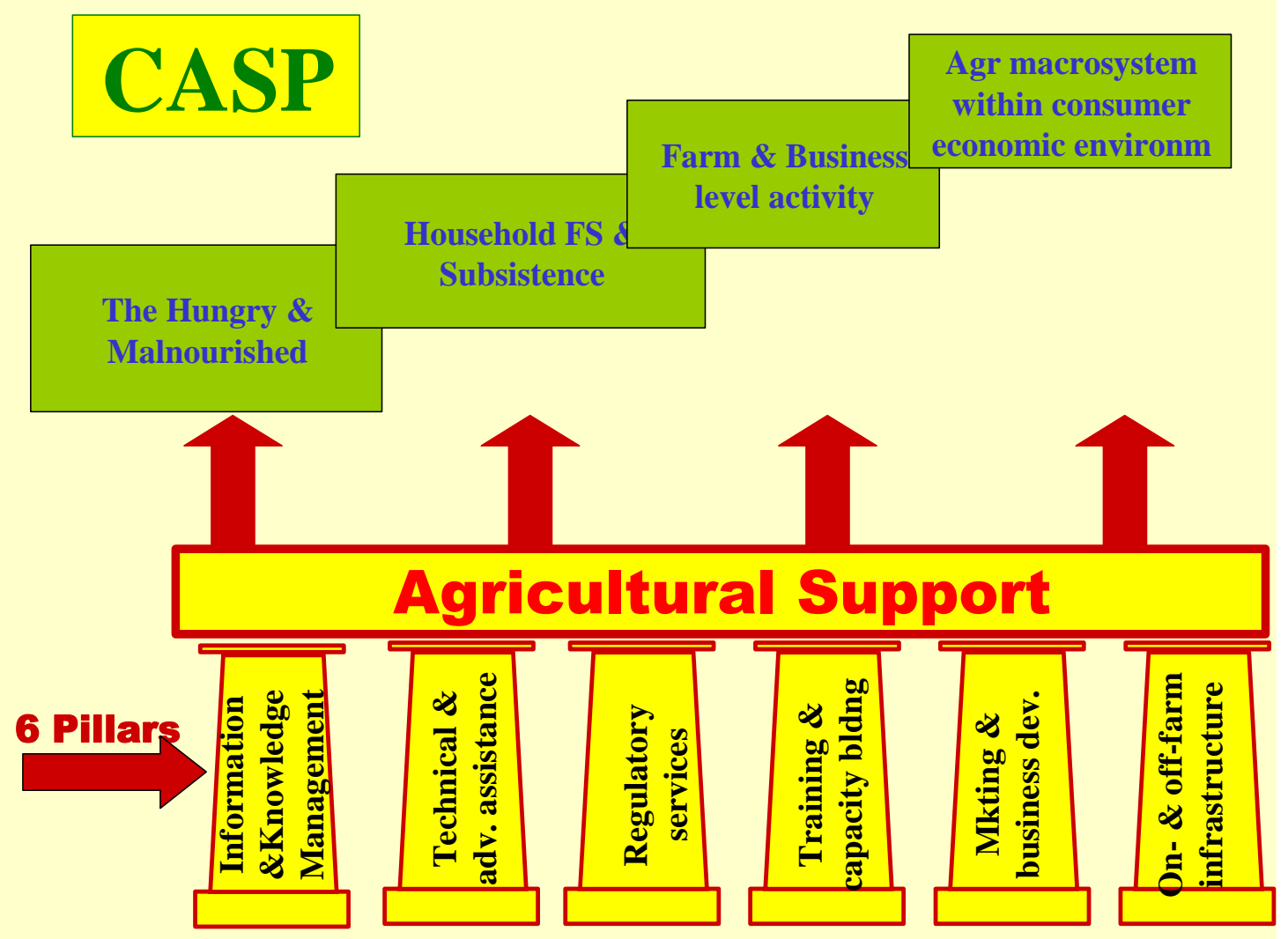

Figure 2 Comprehensive Agricultural Support Programme

Source: Department of Agriculture, 2004. A Draft document for Deputy Director-General: Agricultural Production and Resource Management of the Department of Agriculture

The following Tables 2 to 6 indicate the Comprehensive Agricultural Support Programme allocation and expenditure in Rands from 2004/05 to 2011/12, budget allocation per province from 2004/05 to 2011/12 and budget allocation to the six pillars for the year 2011/12.

Table 1 Agricultural budget allocation, expenditure and targeted beneficiaries of CASP from 2004/5 to 2011/12

\begin{tabular}{|l|l|l|l|l|}
\hline Year & $\begin{array}{l}\text { Budget } \\
\text { R'000 }\end{array}$ & $\begin{array}{l}\text { Expenditure } \\
\text { R' 000 }\end{array}$ & $\begin{array}{l}\text { Targeted } \\
\text { Projects }\end{array}$ & $\begin{array}{l}\text { Targeted } \\
\text { beneficiaries }\end{array}$ \\
\hline $2004 / 05$ & 200 & 124 & 510 & 46500 \\
\hline $2005 / 06$ & 250 & 158 & 1070 & 53200 \\
\hline $2006 / 07$ & 300 & 252 & 870 & 67400 \\
\hline $2007 / 08$ & 415 & 333 & 786 & 60300 \\
\hline $2008 / 09$ & 535 & 402 & 703 & 31039 \\
\hline $2009 / 10$ & 715 & 695 & 888 & 26266 \\
\hline $2010 / 11$ & 862 & 854 & 1271 & 27972 \\
\hline $2011 / 12$ & 1029 & 985 & 814 & 37999 \\
\hline Total & 4306 & 3803 & 6912 & 350676 \\
\hline
\end{tabular}


Source: Department of Agriculture, Forestry and Fisheries, 2012; 2011; 2010; 2009. Comprehensive Agricultural Support Programme: Annual Reports.

Table 1 shows the agricultural budget allocation, expenditure, targeted projects and targeted beneficiaries. In the year 2004/05, budget allocated was R200 000 with 124000 expenditure on targeted projects of about 510. However, 46500 benefitted from the allocated budgets. Also, in 2005/06, 2006/07, 2007/08, 2008/09, 2009/10, 2010/11 and 2011/12 recorded 250 budget allocation, 158 expenditure, 1070 targeted projects, and targeted beneficiaries of 53 200 respectively.

Table 2 Provincial agricultural budget allocation of CASP from 2004/5 to 2011/12

\begin{tabular}{|l|l|l|l|l|l|l|l|l|l|}
\hline $\begin{array}{l}\text { Provin } \\
\text { ce }\end{array}$ & 2004/05 & $2005 / 06$ & $2006 / 07$ & $2008 / 09$ & $2009 / 10$ & $2010 / 11$ & $2011 / 12$ & Total \\
\cline { 2 - 9 } & $\begin{array}{l}\text { Million Rand } \\
\text { R'000) }\end{array}$ \\
\hline EC & 38043 & 47552 & 55869 & 90018 & 120364 & 177475 & 174985 & 712383 \\
\hline FS & 16870 & 21088 & 30466 & 49089 & 65659 & 75772 & 102932 & 361876 \\
\hline GP & 4582 & 5727 & 15723 & 25329 & 33844 & 42187 & 41173 & 168565 \\
\hline KZN & 37016 & 46270 & 30946 & 88037 & 117762 & 147369 & 164691 & 632091 \\
\hline LP & 33428 & 41786 & 50336 & 81103 & 108483 & 144567 & 154398 & 614101 \\
\hline MP & 18903 & 23629 & 32905 & 53019 & 70892 & 81947 & 102932 & 384227 \\
\hline NC & 10518 & 13148 & 22843 & 36807 & 49232 & 58275 & 72052 & 271032 \\
\hline NW & 26876 & 33594 & 42471 & 68432 & 91518 & 113024 & 138812 & 522235 \\
\hline WC & 13764 & 17206 & 26740 & 43084 & 57640 & 63064 & 82346 & 303844 \\
\hline Total & 200000 & 25000 & 308299 & 534918 & 715394 & 903680 & 1034321 & 3970354 \\
\hline
\end{tabular}

Source: Department of Agriculture. 2004. A Draft document for Deputy Director-General: Agricultural Production and Resource Management, Department of Agriculture (2003-05).

Table 2 provides details of the agricultural budget allocation to CASP in Rands from 2004/5 to $2011 / 12$ at provincial level. The total allocated budget for 2004/05, 2005/06, 2006/07, 2008/09, 2009/10, 2010/11 and 2011/12 were 712 383, 361 876, 168 565, 632 091, 614 101, 384 227, 271 032, 522235 and 303844 for Eastern Cape, Free State, Gauteng, KwaZulu-Natal, Limpopo, Mpumalanga, Northern Cape, North West, and Western Cape correspondingly.

Table 3 Provincial agricultural budget expenditure of CASP from 2004/5 to 2011/12.

\begin{tabular}{|l|l|l|l|l|l|l|l|l|}
\hline \multirow{2}{*}{ Province } & $2004 / 05$ & $2006 / 07$ & $2008 / 09$ & $2009 / 10$ & $2010 / 11$ & $2011 / 12$ & Total \\
\cline { 2 - 8 } & R'000 \\
\hline EC & 18368 & 43262 & 81941 & 111300 & 160,901 & 164000 & 579772 \\
\hline FS & 1638 & 23188 & 44376 & 61523 & 64198 & 106102 & 301025 \\
\hline GP & 2724 & 14947 & 23394 & 33844 & 30963 & 28089 & 133961 \\
\hline KZN & 37016 & 13128 & 83900 & 110554 & 147369 & 164691 & 556658 \\
\hline LP & 21679 & 14220 & 81103 & 103148 & 144559 & 139233 & 503942 \\
\hline MP & 15113 & 21706 & 53019 & 73800 & 81735 & 103554 & 348927 \\
\hline NC & 8111 & 15387 & 31398 & 57403 & 54593 & 75630 & 242522 \\
\hline
\end{tabular}




\begin{tabular}{|l|l|l|l|l|l|l|l|}
\hline NW & 6281 & 22752 & 54993 & 86747 & 107718 & 121126 & 399617 \\
\hline WC & 12924 & 14822 & 43840 & 57596 & 62767 & 82383 & 274332 \\
\hline Total & 123,854 & 185,412 & 497,145 & 695,915 & 854,803 & 984,808 & $3,341,937$ \\
\hline
\end{tabular}

Source: Department of Agriculture, 2004. A Draft document for Deputy Director-General: Agricultural Production and Resource Management, Department of Agriculture: 2003-05.

Public Service Commission, 2011. An evaluation of the Comprehensive Agricultural Support Programme (CASP), 2011

Table 3 shows the provincial agricultural budget expenditure of CASP in Rands from 2004/5 to $2011 / 12$ by provinces. The total budget expenditure for CASP for 2004/05, 2005/06, 2006/07, 2008/09, 2009/10, 2010/11 and 2011/12 amounted to 579 772, 301 025, 133 961, $556658,503942,348927,242522,399617$ and 274332 respectively.

Table 4 Provincial agricultural budget allocation to the six pillars of CASP for 2011/12

\begin{tabular}{|l|l|l|l|l|l|l|l|}
\hline \multirow{2}{*}{ Province } & Total & Pillar 1 & Pillar 2 & Pillar 3 & Pillar 4 & Pillar 5 & Pillar 6 \\
\cline { 2 - 8 } & R'000 & \multicolumn{5}{l|}{} \\
\hline EC & 164985 & 0 & 70731 & 9515 & 0 & 84739 & 0 \\
\hline FS & 106372 & 0 & 0 & 30475 & 4387 & 71510 & 0 \\
\hline GP & 23671 & 2371 & 1185 & 2371 & 1185 & 16559 & 0 \\
\hline KZN & 163923 & 41097 & 3906 & 9000 & 100037 & 9883 & 0 \\
\hline LP & 78912 & 0 & 0 & 7891 & 0 & 71021 & 0 \\
\hline MP & 74026 & 0 & 0 & 5724 & 0 & 68302 & 0 \\
\hline NC & 54523 & 0 & 0 & 800 & 0 & 53723 & 0 \\
\hline NW & 111965 & 5148 & 5148 & 8948 & 10297 & 78414 & 4010 \\
\hline WC & 57373 & 0 & 3500 & 8427 & 2000 & 43446 & 0 \\
\hline Total & 835750 & 48616 & 84470 & 83151 & 117906 & 497597 & 4010 \\
\hline
\end{tabular}

Source: Department of Agriculture, Forestry and Fisheries. 2012. Comprehensive Agricultural Support Programme. Annual Evaluation Report: 2012.

Table 4 shows the Provincial agricultural budget allocation to the six pillars of CASP for 2011/12. Pillar 6 is zero because it is covered by Micro Agricultural Financial Institutions of South Africa (MAFISA). Pillar 1(information and knowledge management), pillar 2 (technical and advisory assistance), pillar 3(regulatory services), pillar 4 (training and capacity building) and pillar 5 (marketing and business development) are covered by the Extension Recovery Plan within the CASP.

Table 5 Provincial agricultural budget expenditure for the six pillars of CASP for 2011

\begin{tabular}{|l|l|l|l|l|l|l|l|l|}
\hline \multirow{2}{*}{ Province } & Total & Pillar 1 & Pillar 2 & Pillar 3 & Pillar 4 & Pillar 5 & Pillar 6 \\
\cline { 2 - 8 } & R'000 & \multicolumn{7}{|l|}{$\mid$} \\
\hline EC & 157567 & 0 & 68434 & 8894 & 0 & 80239 & 0 \\
\hline FS & 106102 & 0 & 0 & 30065 & 4191 & 71846 & 0 \\
\hline GP & 14501 & 2101 & 1004 & 953 & 923 & 9520 & 0 \\
\hline KZN & 162363 & 41097 & 3906 & 7440 & 100037 & 9883 & 0 \\
\hline
\end{tabular}




\begin{tabular}{|l|l|l|l|l|l|l|ll|}
\hline LP & 72824 & 0 & 0 & 7887 & 0 & 64937 & 0 \\
\hline MP & 64507 & 0 & 0 & 1503 & 0 & 63004 & 0 \\
\hline NC & 52210 & 0 & 0 & 1058 & 0 & 51152 & 0 \\
\hline NW & 107377 & 4965 & 4158 & 8921 & 3497 & 85836 & 0 \\
\hline WC & 53365 & 0 & 3500 & 4008 & 2000 & 47865 & 0 \\
\hline Total & 790816 & 48163 & 81002 & 66721 & 110648 & 484282 & 0 \\
\hline
\end{tabular}

Source: Department of Agriculture, Forestry and Fisheries. 2012. Comprehensive Agricultural Support Programme. Annual or Evaluation Report: 2011/12.

Table 5 shows the provincial agricultural budget expenditure for the six pillars of CASP for 2011/12. The total budget expenditure for pillar 1-5 for Eastern Cape, Free State, Gauteng, KwaZulu-Natal, Limpopo, Mpumalanga, Northern Cape, North West, and Western Cape were 157 567, 106 102, 14 501, 162 363, 72 824, 64 507, 52 210, 107377 and 53365 respectively.

\section{COMPREHENSIVE AGRICULTURAL SUPPORT PROGRAMME AND IMPLICATION FOR AGRICULTURAL EXTENSION}

Criticism abounds of the ineptitude of advisory services in Sub-Saharan Africa and Extension has been painted negatively (Mutimba, 2014: 18). Nevertheless, numerous studies (MEAS, 2013: 12; Cohen, et.al, 2011:23) indicated that extension advisors are assisting farmers to accomplish their primary goals of becoming creative and productive farmers. But, the daunting challenges faced by extension include inadequate motivation, goal setting and planning, communication and problem solving skills (Agholor AI, 2016:1).

In the recent past, agricultural support has been directed towards land and agrarian reform projects that are aimed at alleviating poverty and job creation; but with the birth of CASP, the focus encapsulated agricultural research and development, human capital, biophysical capital formation, improved institutions and improvement of rural institutions such as extension. Since the inception of CASP in 2004/05, aggregate amount of R750 million has been apportioned to the programme (DAFF, 2018:9). The provision and delivery of agricultural support services is dependent on the capacity of provincial departments. The provincial government is liable for the strengthening of extension services in South Africa. Consequently, extension must be involved in directing the process of planning and implementation of various support effort at provincial level.

Noticeable challenges experienced in the implementation of CASP were inadequate capacity and insufficient financial knowledge at provincial departments. The role of extension amongst others is to redress the operational distortions and financial planning irregularities and also be involved in the process of training Credit and Planning Committees (CPC) of CASP in collaboration with Agri-SETA.

The training and mentorship policy should be legislated to allow extension to guide emerging farmers towards achieving commercial viability. The development of skills for farmers is 
critical for successful implementation of CASP. Extension practitioners must assist beneficiaries to received hands-on training in various fields of farm planning and management. Early weather indicators, advisories and risk management should be promoted by extension to create awareness and help farmers develop confidence. Extension must have a sound knowledge of climate change dynamics and techniques to assist farmers towards building resilience.

\section{CONCLUSIONS}

The conceptualisation of pubic investments is closely linked to some fundamentals of agricultural development and economic growth. The study indicated that there are strong positive returns on investments for the prime movers of agricultural development which include: agricultural research and development, human capital development, biophysical capital formation, improved institutions, particularly, rural institutions, and an enabling macroeconomic and agricultural policy. Studies also clearly substantiate the fact that agricultural development is one of the most powerful tools to eradicate poverty, boost shared prosperity and improve food security. They also corroborate that government plays a key role in supporting agriculture which is fundamental to the generation of employment and economic development of a country. Though, public investment in agriculture has been increased since 2004/05 for the Comprehensive Agricultural Support Programme, however, the pace of investment has been slow and the pattern is skewed towards infrastructural expenditure and commercial farmers. The inadequate public investments to agricultural research and development, and human capital development has slowed the pace of agro-technology with adverse effects on agricultural productivity. However, CASP has made a progressive impact to capacity building in agriculture through skills development and knowledge transfer. Notwithstanding, there are salient and relevant areas in which capacity building has been deficient, such as cultivar selection, livestock infection control and marketing

\section{RECOMMENDATIONS}

Government is expected to fill the investment gap in agriculture. Consequently, the South African government must create a favourable policy and development support environment for private sector (both domestic and foreign agri-business investors) to assist in filling the investment space in agriculture. In light of this, the understanding of prioritisation and harmonisation of public investment in the prime movers of agricultural development, particularly, at lower level, such as, programme level (covered by the Comprehensive Agricultural Support Programme) is very important for South African smallholder agriculture. Government should recognise the pressing need for a more fundamental change in the strategy to allocate and spend public resources and accelerate the pace of addressing the quality of public spending on South African agriculture. Categories of government investment that have considerable positive outcome on productivity and welfare of the citizenry must be accentuated. Nevertheless, South Africa should, therefore, come up with an effective strategies 
of investing to the various prime movers of agricultural development, particularly, for smallholder agriculture.

\section{REFERENCES}

AGHOLOR, A. I. 2016. Self-efficacy: Sources, Physiognomies, Goal realization and Implication for Extension. Proceedings of the South Africa Society of Agricultural Extension (SASAE), 50 ${ }^{\mathrm{TH}}$ Annual conference $4^{\text {th }}-8^{\text {th }}$ June 2016

BHORAT, H., VAN DER WESTHUIZEN, C \& JACOBS. E. 2011. The Role of Agriculture in Poverty Reduction: South Africa. Paper presented at the Centre for Strategic Economic Studies-Australian Centre for International Agricultural Research International Workshop on the role of agriculture in poverty reduction, Melbourne, May 2011. Centre for Strategic Economic Studies, Victoria University: Melbourne

BINUOMOTE, S.O., ADELEKE, O.A. \& OMODUNBI, C.O. 2012. The Effect of Government expenditure on agricultural productivity in Nigeria (1960-2008). A Bounds Testing Approach. Continental Journal of Agricultural Science, 6(2):30-37. From: http://www.wilolujournal.com. (Retrieved 13 JUNE 2017)

BINSWANGER-MKHIZE, H.P. 2014. From failure to success in South African Land Reform. African Journal of Agricultural Resource Economics, 9(4):253-269

BLACKIE, M., BLACKIE, R., LELE, U. \& BEITEMA, N. 2010. Capacity Development and Investment in Agricultural R\&D in Africa. Lead Background Paper. Ministerial Conference on Higher Education in Agriculture in Africa. From: www.forum.org/sites/default/files/File/CHEA/CHEA\%20FINAL/Background\%20pap ers/Capacity\%20\&\%20Investment. (Retrieved on 18th June 2018)

BLEAKLEY, H. 2010. Health, Human Capital, and Development. Annual Review of Economics 2: 283-310

BUSINESS ENTERPRISES. 2014. Impact Evaluation of the Comprehensive Agricultural Support Programme. Draft. Pretoria: The Presidency, Republic of South Africa.

CENTRE FOR ALLEVIATION OF POVERTY THROUGH SUSTAINABLE AGRICULTURE. 2012. The Role of Policies in Agricultural Transformation. Centre for Alleviation of Poverty through Sustainable Agriculture (CAPSA) Working Paper No.106. From: http://www.uncapsa.org/publication/WP106.pdf. (Retrieved on 29 May 2018).

COHEN, M.J. \& LEMMA, M., 2011. Agricultural extension services and gender equality: An institutional analysis of four districts in Ethiopia. IFPRI Discussion Paper No. 1094. Washington, D.C., United States of America

DEPARTMENT OF AGRICULTURE, FORESTRY AND FISHERIES, 2018. From: https://www.daff.gov.za/daffweb3/Programme/Comprehensive-Agricultural-SupportRetrieved on 7 January 2019 
DEPARTMENT OF AGRICULTURE, FORESTRY AND FISHERIES. 2014. Comprehensive Agricultural Support Programme Annual Report. From: www.daff.gov.za/Annual\%20Report/Annual\%20Report\%20for\%20\%2020132014.pdf. Retrieved on 15 April 2018

DEPARTMENT OF AGRICULTURE, FORESTRY AND FISHERIES. 2012. A framework for the development of smallholder farmers through cooperative development. Directorate Co-operative and Enterprise Development. Pretoria, South Africa. From: http://www.daff.gov.za. Retrieved on 13 November 2018

DEPARTMENT OF AGRICULTURE, FORESTRY AND FISHERIES. 2012. Comprehensive Agricultural Support Programme (CASP). Annual Report for CASP: 2011/12. Department of Agriculture, Forestry and Fisheries. From: http://www.daff.gov.za. Retrieved on 29April 2018

DEPARTMENT OF AGRICULTURE, FORESTRY AND FISHERIES. 2011. Agricultural Statistics. Department of Agriculture, Forestry and Fisheries. From: http://www.daff.gov.za. Directorate Economic Services: Division of Economic Research. (Retrieved on 29 May 2018)

DEPARTMENT OF AGRICULTURE, FORESTRY AND FISHERIES. 2011.Comprehensive Agricultural Support Programme. Annual Report for CASP. Department of Agriculture, Forestry and Fisheries. From: http://www.daff.gov.za. Retrieved on 29 April 2018

DEPARTMENT OF AGRICULTURE, FORESTRY AND FISHERIES. 2010. Comprehensive Agricultural Support Programme. Annual Report for CASP. Department of Agriculture, Forestry and Fisheries. From: http://www.daff.gov.za. Retrieved on 30 April 2018

DEPARTMENT OF AGRICULTURE, FORESTRY AND FISHERIES. 2009. Comprehensive Agricultural Support Programme. Annual Report for CASP. Department of Agriculture, Forestry and Fisheries. From: http://www.daff.gov.za. Retrieved on 30 April 2018

DEPARTMENT OF AGRICULTURE. 2004. Comprehensive Agricultural Support Programme (CASP): A Draft document for the Deputy Director-General Progress Report 2003-2005. From: http://www.daff.gov.za. Retrieved on 19 November 2017

FOOD AND AGRICULTURE ORGANIZATION. 2012. The State of Food and Agriculture: Investing in agriculture for a better future. Food and Agriculture Organisation of the United Nations, Rome. From: http://www.fao/catalog/inter_e.htm. Retrieved on 15 March 2018

FOOD AND AGRICULTURE ORGANIZATION, 2012. The State of Food insecurity in the World 2012. Food and Agriculture Organisation of the United Nations, Rome. From: http://www.fao.org/docrep/016/i3027e/i3027e.pdf. Retrieved on 25 May 2017

FLAHERTY, K., LIEBENBERG, F. AND KIRSTEN, J. 2010. South Africa: Recent Development in public agricultural research. ASTI. From: http://www.asti.cgiar.org/south_africa. Retrieved on 23 September 2017 
GAUTENG PROVINCIAL GOVERNMENT ECONOMIC REVIEW AND OUTLOOK. 2012. From: http://www.finance.gpg.gov.za/GDFDocuments/PERO/Provincial\% Retrieved on 21 July 2013

GORE, S.D.V. AND SHINDE, N.D. 2014. An Analysis of Capital Formation in Indian Agriculture and ITS Implications for More Inclusive Growth of Indian Economy. Journal of Poverty, Investment and Development, 6:1-5. From: www.iiste.org. Retrieved on 11December 2018

GOYAL, A. AND NASH, J. 2016. Reaping Richer Returns: Public Spending Priorities for African Agriculture Productivity Growth. World Bank, Africa Development Forum. From: http://openknowledge.worldbank.org. Retrieved on 11 December 2018

GREENBERG, S. 2010. Status report on land and agricultural policy in South Africa. Research Report No. 40. PLAAS. School of Governance, University of Western Cape. From: http://repository.uwc.ac.za/xmlui/bitstream/handle/10566/657/RR400.pdf? sequence $=1$. Retrieved on 13 May 2018

GREWAL, B., GRUNFELD, H. AND SHEEHAN, P. 2012. The Contribution of Agricultural Growth to poverty reduction. ACIAR Impact Assessment Series Report No.76. Australian Centre for International Agricultural Research (ACIAR): Canberra. 59pp

HALL, R. AND ALIBER, M. 2010. The Case for Restrategising Spending Priorities to Support Small-Scale Farmers in South Africa. Institute for Poverty, Land and Agrarian Studies (PLAAS), Working Paper 17, University of the Western Cape

JACOBS, P., BAIPHETHI, M., NGCOBO, N. AND HART, T. 2010. The potential of social Grants expenditure to promote local economic development and job creation. Centre for Poverty Employment and Growth. Pretoria: Human Sciences Research Council

KIBUUKA, E. AND MNYAKA, M. 2013. Developing an Agricultural Statistics Strategy for South Africa. From: http://www.statssa.gov.za. Retrieved on 6 August 2018

LIEBENBERG, F. 2015. Agricultural Advisory Services in South Africa. Discussion Paper Department of Agricultural Economics, Extension and Rural Development, Faculty of Natural and Agricultural Sciences, University of Pretoria. Pretoria

MINISTRY OF AGRICULTURE AND LAND AFFAIRS. 2006. Land and Agrarian Reform in South Africa: 1994-2006. Pretoria

MODERNIZING EXTENSION AND ADVISORY SERVICES (MEAS), 2013. Extension and advisory service delivery for women's groups in Jordan: Assessing competencies and building social capital. Available from: https://sites.google.com/a/measextension.org/safety_2013_07_31/meas-offers/pilot-projects/gender-research-jordan

MOGUES, T., YU, B., FAN, S. AND MCBRIDE, L. 2012. The Impacts of Public Investment in and for Agriculture: Synthesis of the Existing Evidence. From: 
http://www.ifpri.org/sites/default/files/publications/ifpridpo1217.pdf. Retrieved on 5 February 2018

MOGUES, T. 2012a. What Determines Public Expenditure Allocations? A Review of Theoretical and Implications for Agricultural Public Investment. IFPRI, Washington, D.C. From: http://www.ifpri.org/sites/default/Files/publications/ifpridp01216.pdf. Retrieved on $21^{\text {st }}$ June 2018

MOHAMMAD, A.D.T. AND JALIL, T. 2011. An Empirical Analysis of Total Factor Productivity in the Economy of Iran. International Conference on Economics and Finance Research IPEDR, 4, 2011 SIACSIT Press, Singapore

MTHOMBOTHI, B. 2018. It's Criminal the Way we are Unable to Deal with our Crime. Sunday Times. September 16, 2018., p. 17

NATIONAL PLANNING COMMISSION. 2011. National Development Plan: Vision for 2030. National Planning Commission. Pretoria: From: http//www.npconline.co.za/medialib/downloads/home/NPC\%20National\%20Develop ment\%20Plan\%20Vision\%202030\%20-lo-res-pdf. Retrieved on 5 May 2018

NEW PARTNERSHIP FOR AFRICA'S DEVELOPMENT- COMPREHENSIVE AFRICA AGRICULTURE DEVELOPMENT PROGRAMME. 2010. Comprehensive Africa Agriculture Development Programme). Pillar 4: Agricultural Research. From: http://www.nepad-caadp.net/pillar-4.php. Retreived on 6 November, 2018

NORTON, G.W., ALWANG, J. AND MASTER, W.A. 2010. Economics of Agricultural Development: World food systems and resources use, $2^{\text {nd }}$ Edition. Routledge, Taylor and Francis Group, London and New York

PROGRAMME TO SUPPORT PRO-POOR POLICY DEVELOPMENT. 2011. The Programme to support pro-poor policy development (PSPPD). Institute of Poverty, Land and Agrarian Studies (PLAAS). From: www.psppd.org.za/publication-pdf. Retrieved on 13 December 2017

PUBLIC SERVICE COMMISSION. 2011. Public Service Commission: An Evaluation of the Comprehensive Agricultural Support Programme (CASP), September, 2011

SIKWELA, M. M. AND MUSHUNJE, A. 2013. The Impact of Farmer Support Programmes on Household Income and Sustainability in Smallholder Production: A case study of the Eastern Cape and KwaZulu-Natal farmers, South Africa. From: http://www.academicjournals.org/AJAR, 8(21):2502-2511. Assessed on: $7^{\text {th }}$ January 2018

SINGH, A. AND PAL, S. 2010. The Changing Pattern and Sources of Agricultural Growth in India. In: The Shifting Patterns of Agricultural Production and Productivity Worldwide. From: $\quad$ http://www.card.iastate.edu/books/shifting_patterns/pdfs/Chapter11.pdf. Retrieved on 22 July 2017 
S. Afr. J. Agric. Ext.

Mncina, Agholor

Vol. 49 No. 1, 2021: 122-140

http://dx.doi.org/10.17159/2413-3221/2021/v49n1a10782

(License: CC BY 4.0)

VAN NIEKERK, L. 2012. South African Agriculture. Pocket Guide to South Africa 2011/12. Government Communication and Information System. From: http://www.info.gov.za/aboutsa/agriculture/htm. Retrieved on 28 May 2018

WOODE ME. 2017. Parental health shocks and schooling: The impact of mutual health insurance in Rwanda. Soc Sci Med. 173:35-47 